\title{
PERAN E-SERVICE QUALITY, KEMUDAHAN, KEPUASAN DALAM MEMBENTUK NIAT BELI ULANG KONSUMEN LAZADA
}

\author{
Dhimas Bagus Dwicahyanto \\ Universitas Negeri Surabaya \\ dhimasd@mhs.unesa.ac.id
}

Abstract

\begin{abstract}
Lazada is a market leader of e-commerce in Shout-East Asia. This study aims to analyze and discuss the effect of the e-service quality and eases on the repurchase intention through satisfaction. This study uses college students aged 18-25 years as respondents, which have purchased Lazada at least once, and their last purchase is in the last one month. The sampling method is non-probability sampling using a snowball sampling technique. The number of samples is 220 respondents. Data were collected by an online questionnaire and analyzed using AMOS. The result of this study indicates that e-service quality and ease have a significant effect on satisfaction and repurchase intention.
\end{abstract}

Keywords: e-service quality; ease; consumer satisfaction; repurchase intention.

\section{PENDAHULUAN}

Di zaman modernisasi seperti ini, kebergantungan manusia terhadap teknologi menjadikan teknologi itu sendiri sebagai kebutuhan dasar setiap orang dalam berbagai aspek kehidupan. Dengan masuknya internet dalam dunia bisnis, kini banyak perusahaan berlomba dalam mengkombinasikan bisnisnya menjadi bisnis yang berbasis elektronik atau yang biasa disebut dengan e-business (Swastika, 2015). Lupiyoadi (2013:286) mengatakan bahwa e-bussiness dalam arti bisnis internet adalah penggunaan internet dalam kaitan membangun hubungan dengan konsumen dan juga mitra bisnis. Era bisnis tradisional dan gaya hidup juga berubah seiring pertumbuhan internet pada e-business itu sendiri.

Menurut Lupiyoadi (2008:273), e-commerce jika menurut model bisnisnya dapat dibagi menjadi forum tidak hanya online dan iklan baris, tetapi juga website business to consumers (B2C), marketplace consumer to consumer $(C 2 C)$, dan lainnya. Toko online merupakan salah satu industri yang berkembang dari website Business to Consumer. E-commerce merupakan perusahaan atau situs fasilitas untuk membantu transaksi penjualan produk secara online (Kotler \& Keller (2009:132). Bitner et al. (2003) mengatakan bahwa aktivitas e-business yang memanfaatkan teknologi ini akan memengaruhi pola pelayanan yang selama ini berlangsung.

Survei yang dilakukan oleh CNN Indonesia (2018) menunjukkan bahwa sebanyak 86\% (147,2 juta) pengguna internet mengakses online shop. Pertumbuhan pengguna internet juga disebabkan oleh peningkatan akses internet menggunakan piranti mobile. Ponsel dan koneksi broadband mobile yang saat ini terjangkau adalah pendorong pertumbuhan akses internet. Peningkatan akses internet melalui piranti mobile ini akan berdampak pada transaksi jual beli yang terjadi secara online (Yusuf, 2014).

Menurut Kotler dan Keller (2009:136), konsumen dan pebisnis tidak lagi harus mengirim dan mendapatkan informasi melalui komputer karena kebutuhannya sudah digeser oleh gawai seluler. Ketika mereka sedang bepergian, mereka dapat terhubung ke internet untuk memeriksa harga saham, cuaca, melihat skor pertandingan olahraga, mengirimkan dan menerima e-mail, juga melakukan pesanan online. Hal ini menunjukkan bahwa kemudahan adalah hal yang harus diperhatikan oleh perusahaan. Gambar 1 menunjukkan data penelitian terhadap pengguna internet di indonesia menurut perangkat yang dipakai, survey yang dilakukan oleh APJII pada 2018.

M-commerce dikembangkan dari e-commerce yang pada prakteknya hanya menggunakan jaringan wireless atau mobile telecommunication. Banyak perusahaan memanfaatkan e-commerce yang kemudian diintegrasikan dengan m-commerce sebagai sarana penghubung antara penjual dan konsumen antara lain, bukalapak.com, tokopedia.com, lazada.co.id, olx.co.id, kaskus.co.id dan masih banyak lagi 
Dhimas Bagus Dwicahyanto. Peran E-Service Quality, Kemudahan, Kepuasan dalam Membentuk Niat Beli Ulang Konsumen Lazada

adalah contoh situs online yang menjual produk. M-commerce yang dimaksud disini adalah basis aplikasi yang mereka miliki pada 2 platform smartphone, baik android pada Play Store maupun ios pada App Store. Salah satu e-commerce yang juga menerapkan $m$-commerce di Indonesia ialah Lazada. Situs e-commerce Lazada didirikan pada tahun 2012 oleh Samwer bersaudara yang juga merupakan orang di belakang Rocket Internet. Situs ini dikenal sebagai kloning dari raksasa e-commerce Amazon di Amerika. Namun berbasis pada negara berkembang seperti Indonesia, Malaysia, Filipina, Thailand, dan Vietnam saat pertama kali diluncurkan (venturebeat.com, 2013).

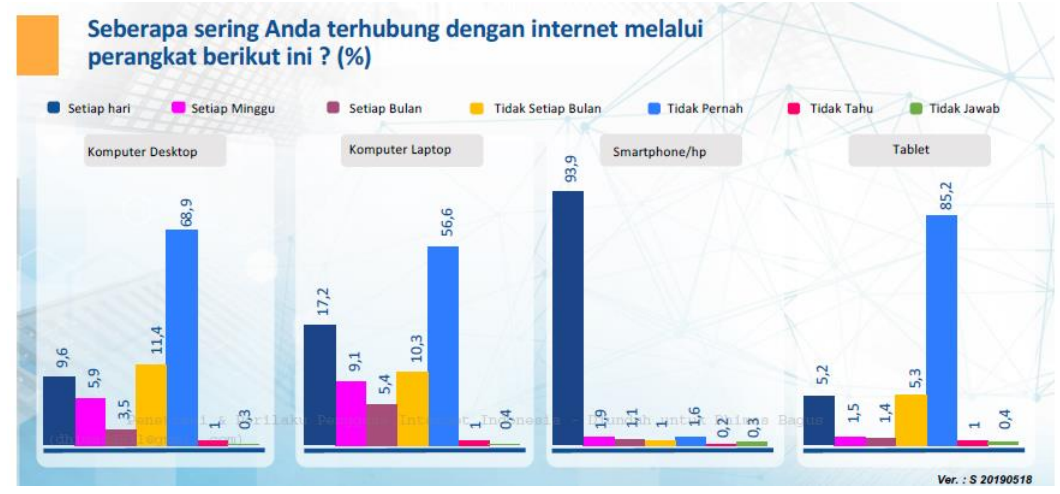

Sumber: APJII (2018)

\section{Gambar 1. JUMLAH PENGGUNA INTERNET DI INDONESIA MENURUT PERANGKAT YANG DIPAKAI}

Lazada.co.id mendapatkan penghargaan 3 tahun berturut-turut sebagai perusahaan yang mengedepankan kepuasan konsumen oleh Indonesian Customer Satisfaction Award (ICSA) pada tahun 2015, 2016 dan 2017 (ICSA, 2017). Lazada telah meningkatkan berbagai aspek seperti; pengiriman yang lebih ditingkatkan untuk memotong waktu pengiriman dua kali lebih cepat dari sebelumnya bekerja sama dengan 51 kurir, prosedur pengembalian yang mudah, masuknya sistem pembayaran alipay dan tersedianya 7juta produk dari total 15.000 penjual (Marzuki, 2017).

Namun hal ini berbanding terbalik dengan survei yang dilakukan Popular Brand Index (PBI) di tahun 2017 dan 2018. Niat beli ulang pada Lazada menurun 6,1 poin dari tahun 2017 sebesar 27,5 menjadi 20,4 pada tahun 2018. Top of mind pada Lazada menurun 12,6 poin dari tahun 2017 sebesar 46,3 menjadi 33,7 pada tahun 2018 (Nusaresearch, 2018).

Ulasan buruk juga berdatangan dari konsumen yang melakukan transaksi di Lazada menggunakan aplikasi pada smartphone mereka (Trustedcompany.com, 2018). Padahal, Lazada Indonesia mengungkapkan bahwa kontribusi transaksi melalui platform mobile sebesar 60\%. Data ini membuktikan tepatnya pilihan Lazada untuk berinvestasi pada platform mobile. Namun dari banyak hal yang menunjukkan ketidakpuasan pengguna terhadap layanan Lazada (Siregar, 2016).

Penelitian ini menganalisis pengaruh pengaruh e-service quality dan kemudahan terhadap niat beli ulang dengan melalui kepuasan.

\section{KAJIAN PUSTAKA DAN PENGEMBANGAN HIPOTESIS}

\section{E-Service Quality}

E-service quality merupakan pengukuran keefektifan dan keefisienan situs web dalam memfasilitasi belanja, pembelian, dan pengiriman produk dan jasa (Zeithaml, Parasuraman \& Malhotra, 2002). Eservice sebagai istilah yang digunakan untuk layanan jasa yang menggunakan internet (Swaid \& Wigand (2009:13). Menurut Wolfinbarger dan Gilly (2003), walaupun studi akan service quality juga $e$-service quality telahd ilakukan, dan dikembangkan juga skala yang berbeda untuk mengukur $e$-service quality, penelitian yang ada mengenai e-service quality telah dideskripsikan secara terpisah. Merujuk dari hasil kajian dan pendapat dari para ahli di atas maka yang dijadikan pengukuran dari E-Service Quality menggunakan hasil penelitian Parasuraman et al (1994), dan diintegrasikan dengan penelitian 
terbaru Parasuraman et al (2005) yang sudah disesuaikan dengan obyek dari kajian dan indikator yang akan digunakan dalam penelitian, antara lain: berwujud, keandalan, daya tanggap, jaminan, empati, pemenuhan, ketersediaan sistem, dan privasi.

\section{Kemudahan}

Seberapa jauh teknologi komputer dirasa relatif mudah dipahami dan digunakan disebut dengan perceived ease of use (Davis et al., 1989 dalam Chin dan Todd, 1995). Merujuk dari hasil kajian dan pendapat dari para ahli di atas maka yang dijadikan pengukuran dari kemudahan menggunakan hasil penelitian Amijaya (2010), Anindita (2016) dan Wen et al. (2011) yang sudah disesuaikan dengan obyek dari kajian dan indikator yang akan digunakan dalam penelitian, antara lain: mudah dipelajari, efisiensi waktu, situs yang fleksibel, dan situs mudah digunakan.

\section{Kepuasan Konsumen}

Menurut Irawan (2004:20), kepuasan merupakan sebuah upaya untuk memenuhi atau membuat sesuatu yang memadai. Kepuasan juga dapat didefinisikan sebagai persepsi tentang sesuatu yang telah memenuhi harapannya. Kotler dan Keller (2009:139) mengatakan bahwa kepuasan adalah perasaan seseorang karena membandingkan kinerja atau hasil yang dirasakan dari dengan harapan mereka. Menurut Sumarwan (2014:387), kepuasan adalah dorongan bagi konsumen untuk membeli dan kembali mengkonsumsi produk. Sebaliknya, perasaan tidak puas akan menyebabkan konsumen kecewa dan berhenti membeli dan kembali mengkonsumsi produk. Merujuk dari hasil kajian dan pendapat dari para ahli di atas maka yang dijadikan pengukuran dari kepuasan konsumen menggunakan hasil penelitian Fang et al (2011), Fang (2014), dan Shiau (2012) yang sudah disesuaikan dengan obyek dari kajian dan indikator yang akan digunakan dalam penelitian, antara lain: Kualitas pengiriman, Kualitas layanan, Keamanan berbelanja online, Fitur desain website, dan Perasaan konsumen tentang pengalaman berbelanja pada toko online.

\section{Niat Beli Ulang}

Niat pembelian ulang menurut Blackwell et al. dalam Maulana (2007:35) berarti niat untuk membeli kembali merefleksi apakah konsumen akan membeli merek yang sama di masa depan. Perilaku pembelian kembali sering dikaitkan dengan loyalitas. Merujuk dari hasil kajian dan pendapat dari para ahli di atas maka yang dijadikan pengukuran dari niat beli ulang menggunakan hasil penelitian Bao et al. (2016), Chiu et al. (2009) dan Puspitasari (2006) yang sudah disesuaikan dengan obyek dari kajian dan indikator yang akan digunakan dalam penelitian, antara lain: Niat untuk melakukan pembelian ulang pada toko online, Niat untuk melakukan pembelian ulang pada toko online yang sama dalam waktu dekat, Frekuensi pembelian dan barang yang dibeli lebih banyak, dan rekomendasi positif.

\section{Hubungan antar Variabel}

Menurut penelitian yang telah dilakukan Hafeez (2012), Fernanda (2013), Mosahab (2010), Sumaedi et al, (2011), dan Tuan (2012), kualitas layanan berpengaruh positif terhadap kepuasan. Sejalan dengan hal tersebut, Kandulapati (2014) membuktikan hubungan e-service quality dengan kepuasan konsumen.

\section{H1: E-service quality berpengaruh terhadap kepuasan konsumen pelanggan Lazada.}

Tu et al. (2012) membuktikan pengaruh kemudahan terhadap kepuasan dan loyalitas. Hasil tersebut menunjukkan bahwa kemudahan berpengaruh positif terhadap kepuasan. Wen et al. (2011) menunjukkan bahwa faktor kemudahan berpengaruh secara langsung terhadap kepuasan dan niat beli ulang pada konsumen toko online. Indikator kemudahan menurut Hardiawan (2013) adalah mudah dipelajari, mudah mengoperasikan sistem sesuai apa yang diinginkan, mudah digunakan, dan efisiensi waktu.

H2: Kemudahan berpengaruh terhadap kepuasan konsumen pelanggan Lazada.

Lin (2014) menunjukkan bahwa semakin puas konsumen, semakin konsumen berniat melalukan pembelian ulang secara online. Penelitian Fang (2014) juga menunjukkan bahwa kepuasan konsumen berpengaruh terhadap niat beli ulang pada toko online tanpa melalui variabel intervening. Tsiotsou 
Dhimas Bagus Dwicahyanto. Peran E-Service Quality, Kemudahan, Kepuasan dalam Membentuk Niat Beli Ulang Konsumen Lazada

(2006) menunjukkan bahwa kepuasan merupakan indikator utama dari perilaku pembelian (pembelian ulang, membeli produk lain). Hizza et al. (2014) membuktikan kepuasan konsumen berpengaruh signifikan positif terhadap loyalitas online dalam lingkungan belanja online. Begitu juga dengan penelitian Dholakia (2010) yang menunjukkan kepuasan konsumen sangat berpengaruh terhadap niat pembelian ulang.

H3: Kepuasan berpengaruh terhadap niat beli ulang pelanggan Lazada.

Penelitian Wibowo et al. (2013) menunjukkan kualitas pelayanan dan kepuasan memengaruhi niat beli ulang. Hasil tersebut menunjukkan kualitas layanan berpengaruh positif pada kepuasan kemudian pada niat beli ulang. Kualitas layanan juga terbukti berpengaruh positif terhadap kepuasan (Adixia, 2013).

H4: E-service quality berpengaruh terhadap niat beli ulang pelanggan Lazada.

Penelitian Wen et al. (2011) membuktikan kemudahan berpengaruh secara langsung terhadap kepuasan konsumen dan niat beli ulang pada konsumen toko online. Selain itu, Chang (2012) menyatakan bahwa kemudahan penggunaan berdampak positif terhadap manfaat yang dirasakan. Kemudahan penggunaan meningkatkan kepuasan dengan ditunjukkan oleh pembelian berulang.

H5: Kemudahan berpengaruh terhadap niat beli ulang pelanggan Lazada.

\section{METODE PENELITIAN}

Penelitian ini merupakan penelitian kausalitas Populasi dalam penelitian ini adalah masyarakat pelanggan Lazada yang berusia 18-25 tahun yang merupakan pelajar atau mahasiswa. Penelitian ini menggunakan sampel dengan metode non probability sampling yakni snowball sampling dengan kuisioner online.

Data dianalisis menggunakan Analisis Jalur (Path Analysis) dengan AMOS 22 dengan melakukan uji validitas dan reliabilitas pada 30 responden awal. Periode penyebaran data dilakukan pada kurun waktu kurang lebih 3 bulan dari 15 Mei-29 Agustus 2019. Jumlah data responden yang terkumpul adalah sebanyak 210 responden. Selanjutnya adalah dilakukan uji asumsi dengan uji linieritas dan normalitas, uji outlier, uji analisis jalur, uji hipotesis, dan uji sobel tes untuk melihat peran mediasi pada penelitian ini.

\section{HASIL DAN PEMBAHASAN}

\section{Uji Validitas}

Hasil pada perhitungan diperoleh nilai corrected item-total correlation pada tiap variabel dinyatakan valid yaitu di atas $>0,361$. Dan hasilnya semua indikator pada variabel e-service quality, kemudahan, kepuasan konsumen, dan niat beli ulang dinyatakan valid.

\section{Uji Reliabilitas}

Uji reliabilitas diperoleh hasil cronbach alpha lebih tinggi dibanding $>0,70$. Hasil perhitungan cronbach alpha diperoleh e-service quality sebesar 0,966, kemudahan 0,892, kepuasan sebesar 0,922, dan niat beli ulang sebesar 0,913 .

\section{Uji Outlier}

Uji outlier pada AMOS dilakukan dengan melihat nilai P2 pada mahalonibis distance. Nilai P2 harus $\geq 0,001$. Setelah diperiksa dengan mahalanobis distance, tidak terdapat pengamatan yang terdeteksi sebagai outlier.

\section{Uji Normalitas}

Uji normalitas dilakukan dengan menggunakan kriteria critical ratio skewness value dengan ketentuan nilai berada pada ring $-2,58 \leq 2,58$ akan dikatakan normal. Setiap variabel menunjukkan distribusi 
normal dan berdasarkan uji normalitas multivariat adalah sebesar 0,052 , sehingga asumsi normalitas multivariat telah terpenuhi dan data layak digunakan dalam estimasi.

Tabel 2.

\section{HASIL UJI HIPOTESIS}

\begin{tabular}{cccc}
\hline Hipotesis & Variabel & CR & P \\
\hline H1 & Kepuasan $\leftarrow$ E-Service Quality & 12,616 & 0.000 \\
H2 & Kepuasan $\leftarrow$ Kemudahan & 17,617 & 0.000 \\
H3 & Niat Beli Ulang $\leftarrow$ Kepuasan & 8,180 & 0.001 \\
H4 & Niat Beli Ulang $\leftarrow$ E-Service Quality & 6,699 & 0.007 \\
H5 & Niat Beli Ulang $\leftarrow$ Kemudahan & 9,853 & 0.000
\end{tabular}

Sumber: Output AMOS

Tabel 2 menunjukan bahwa hasil uji hipotesis pada penelitian ini dengan melihat nilai signifikansi $\geq 0,05$ yaitu pada $\mathrm{H} 1$ terdapat nilai $\mathrm{CR}$ hitung antara variabel e-service quality terhadap kepuasan adalah $12,616>2,00$ dan nilai probabilitas signifikansinya adalah $0,000(\mathrm{p} \leq 0,05)$. H1 dapat dibuktikan. Nilai CR hitung antara variabel kemudahan terhadap kepuasan adalah 17,617>2,00 nilai probabilitas signifikansinya adalah $0,000(\mathrm{p} \leq 0,05)$, sehingga $\mathrm{H} 2$ terbukti. Pada hipotesis ketiga terdapat nilai CR hitung antara variabel kepuasan terhadap niat beli ulang adalah 8,180>2,00 nilai probabilitas signifikansinya adalah $0,001(\mathrm{p} \leq 0,05)$. Penelitian ini membuktikan H3. Pada hipotesis keempat terdapat nilai CR hitung antara variabel $e$-service quality terhadap niat beli ulang adalah 6,699>2,00 nilai probabilitas signifikansinya adalah $0,007(\mathrm{p} \leq 0,05)$. H4 terbukti. Lalu pada hipotesis kelima terdapat nilai CR hitung antara variabel kemudahan terhadap niat beli ulang adalah 9,853>2,00 nilai probabilitas signifikansinya adalah $0,000(\mathrm{p} \leq 0,05)$. H5 dapat dibuktikan dalam penelitian ini.

Hasil uji mediasi pertama antara variabel e-service quality (X1) signifikan terhadap kepuasan (Z) karena memiliki nilai probabilitas 0,000 serta variabel e-service quality (X1) signifikan terhadap niat beli ulang (Y) juga memiliki nilai 0,000 karena nilai $\mathrm{P}$ berada di bawah 0,05, maka dari itu tes mediasi pertama dapat dibuktikan secara parsial, dan pada hasil uji mediasi kedua antara variabel kemudahan (X2) terhadap kepuasan (Z) memiliki nilai 0,000 dan variabel kemudahan (X2) signifikan terhadap variabel niat beli ulang (Y) memiliki nilai probabilitas 0,000 karena nilai $\mathrm{P}$ berada di bawah 0,05 , maka dari itu uji mediasi ketiga dianggap secara parsial terbukti.

\section{Uji Sobel}

Uji Sobel test digunakan untuk menguji apakah ada peran mediasi terhadap variabel $\mathrm{X}$ dengan variabel $\mathrm{Y}$ dan diperoleh hasil bahwa nilai probabilitas e-service quality $\left(\mathrm{X}_{1}\right)$ dan kemudahan $\left(\mathrm{X}_{2}\right)$ signifikansinya sebesar $0,000(\mathrm{p} \leq 0,05)$. Ini menunjukkan variabel e-service quality $\left(\mathrm{X}_{1}\right)$ dan kemudahan $\left(\mathrm{X}_{2}\right)$ memiliki pengaruh yang signifikan terhadap kepuasan dan niat beli ulang. Artinya, uji mediasi melalui sobel test diterima.

\section{Pengaruh E-Service Quality terhadap Kepuasan}

Hasil penelitian menunjukkan bahwa ada hubungan positif antara e-service quality dan kepuasan. Ketika e-service quality meningkat, kepuasan juga akan meningkat. Ini menjelaskan bahwa $e$-service quality yang lebih baik yang diberikan oleh Lazada melalui layanan yang baik bagi pelanggan mencakup informasi yang lengkap tentang produk, web yang tersedia di Lazada yang tidak pernah mengalami gangguan jaringan dan dengan cepat menangani semua keluhan pelanggan tentang produk dan layanan sehingga pelanggan yang puas.

Hasil ini juga mendukung penelitian Parasuraman et al. (1994) yang mengatakan kualitas layanan adalah seberapa besar perbedaan yang diterima oleh pelanggan, antara kenyataan dan harapan. Penelitian ini juga mendukung penelitian Hafeez (2012) yang menyatakan bahwa kualitas layanan memiliki efek positif pada kepuasan pelanggan. Sejalan dengan penelitian dari Hafeez (2012), menurut 
Fernanda (2013), kualitas layanan memiliki efek positif pada kepuasan pelanggan. Demikian pula menurut Mosahab (2010), kualitas layanan memiliki efek positif terhadap kepuasan pelanggan. Menurut penelitian Sumaedi et al., (2011), kualitas layanan memiliki efek positif terhadap kepuasan pelanggan. Selain itu menurut penelitian Tuan (2012), kualitas layanan memiliki efek positif terhadap kepuasan pelanggan. Menurut Kandulapati (2014), e-service quality mempunyai hubungan dengan kepuasan pelanggan.

Responden yang digunakan di penelitian sebagian besar adalah laki-laki yang berjumlah 117 orang responden, mayoritas dengan usia 18-21 tahun. Jika dikaitkan dengan hasil penelitian, responden lakilaki memilih lebih mementingkan pelayanan yang diberikan berupa tampilan web yang menarik saat mengunjungi situs web Lazada dan nantinya akan memengaruhi pelanggan untuk mencapai kepuasan. Laki-laki selalu mementingkan segi rasionalitasnya sehingga akan selalu membandingkan dahulu pelayanan maupun jaminan dari tiap tiap e-commerce untuk kemudian menjatuhkan pilhan. Seperti halnya dengan pusat perbelanjaan, ditambah makin banyaknya jumlah penyedia layanan sejenis dan pandemi covid-19 yang menggeser cara konsumsi konsumen dari toko fisik ke non-fisik maka sudah seharusnya Lazada lebih memperhatikan tampilan dan jaminan dari e-commercenya. Ini menunjukkan bahwa kualitas layanan adalah salah satu faktor yang dapat mendorong kepuasan pelanggan di Lazada. Berdasarkan hasil ini, Lazada juga sebaiknya memberikan perhatian lebih kepada laki-laki sebagai mayoritas konsumennya.

\section{Pengaruh Kemudahan terhadap Kepuasan}

Melalui analisis jalur dalam penelitian ini menunjukkan pengaruh positif antara variabel kemudahan $\left(\mathrm{X}_{2}\right)$ terhadap variabel kepuasan $(\mathrm{Z})$ pada pelanggan Lazada. Kemudian dapat diartikan bahwa variabel kemudahan memiliki pengaruh yang signifikan terhadap variabel kepuasan. Pada standardized direct effect terlihat pengaruh langsung antara kemudahan terhadap kepuasan. Ini menunjukkan apabila kemudahan positif maka kepuasan akan positif. Sehingga jika semakin mudahnya web Lazada digunakan maka kepuasan konsumen juga ikut semakin baik. Pelanggan mencapai suatu kepuasan apabila saat membuka web Lazada yang tidak membutuhkan waktu lama untuk penggunaan, dapat diakses dengan alat komunikasi apapun yang terhubung dengan internet, dan dapat mempersingkat waktu karena mudah diakses kapan saja dan di mana saja.

Penelitian ini mendukung penelitian Tu et al. (2012) yang membuktikan pengaruh kemudahan terhadap kepuasan pelanggan dan kemudian berpengaruh pada loyalitas konsumen. Hasil ini menunjukkan bahwa kemudahan berpengaruh positif terhadap kepuasan. Wen et al. (2011) menunjukkan bahwa faktor kemudahan secara langsung memengaruhi kepuasan dan niat beli ulang konsumen toko online.

Berdasarkan karakteristik responden didapatkan hasil responden sebagian besar memiliki usia 18-21 tahun yaitu sebanyak 70 orang responden, mayoritas berjenis kelamin laki-laki. Jika dikaitkan dengan jawaban responden, apabila semakin mudah suatu website untuk dipelajari dengan membutuhkan waktu yang singkat untuk belajar disertai tata letak menu web yang mudah dipelajari oleh pelanggan akan meningkatkan kepuasan. Web harus mudah digunakan dengan akses menggunakan alat komunikasi apapun yang berhubungan dengan internet dan fasilitas yang tersedia mudah digunakan akan membuat pelanggan puas. Pelanggan dengan mayoritas laki-laki yang dirasa memiliki tingkat kesabaran lebih rendah akan merasa puas jika web yang terasa efisien secara waktu juga dapat diakses kapan saja dan di mana saja. Pihak Lazada akan selalu dituntut oleh pelanggan untuk menyediakan kebutuhan yang diinginkan setiap waktu karena hal ini merupakan kelebihan dari e-commerce itu sendiri dibanding pusat perbelanjaan fisik. Kondisi pandemi covid-19 yang mengharuskan mengurangi kontak fisik akan membantu konsumen tetap berbelanja kapan saja dengan efisien. Maka dari itu Lazada seharusnya tetap berinvestasi pada terjaganya web yang cepat dan bisa diakses kapan saja tanpa down.

\section{Pengaruh Kepuasan terhadap Niat Beli Ulang}

Hasil penelitian ini menunjukkan pengaruh positif antara variabel kepuasan (Z) terhadap variabel Niat Beli Ulang (Y) studi pada pelanggan Lazada. Sehingga, semakin baik kepuasan yang dirasakan konsumen, semakin baik niat beli ulang. 
Hasil penelitian ini sesuai hasil penelitian Lin (2014) menunjukkan bahwa kepuasan konsumen berpengaruh positif terhadap niat beli ulang online. Penelitian Fang (2014) juga menunjukkan bahwa kepuasan konsumen berpengaruh langsung terhadap niat beli ulang pada toko online. Tsiotsou (2006) menunjukkan bahwa kepuasan sebagai pusat utama dari pemasaran, sehingga dapat menjadi indikator utama dari perilaku pembelian (pembelian ulang, membeli produk lain). Hizza et al. (2014) penelitiannya menunjukkan kepuasan konsumen berpengaruh signifikan positif terhadap loyalitas online dalam lingkungan belanja online. Begitu juga dengan penelitian Dholakia (2010) yang menunjukkan kepuasan konsumen sangat berpengaruh besar terhadap niat pembelian ulang.

Berdasarkan karakteristik responden untuk kriteria frekuensi belanja, didapatkan hasil bahwa responden terbanyak sebagian besar adalah laki-laki yang berjumlah 117 orang responden, mayoritas dengan usia 18-21 tahun. Jika dikaitkan dengan hasil responden tersebut maka laki-laki apabila telah mengalami kepuasan pada suatu produk atau merek maka peluang rata-rata responden yang melakukan belanja online di Lazada dan akan kembali melakukan pembelian sangat besar. Bergesernya pola konsumsi konsumen dari toko fisik ke non-fisik karna pandemi covid-19 sudah seharusnya Lazada terus meningkatkan kepuasan konsumennya agar tetap kembali melakukan pembelian dan tidak berpaling ke penyedia layanan lain. Lazada juga harus tetap menaruh perhatian pada pelanggan lama yang telah bertransaksi disitusnya, dan tidak hanya fokus kepada pelanggan baru saja.

\section{Pengaruh E-Service Quality terhadap Niat Beli Ulang}

Penelitian ini membuktikan pengaruh variabel e-service quality $\left(\mathrm{X}_{1}\right)$ terhadap variabel niat beli ulang (Y) studi pada pelanggan Lazada. Hasil ini mendukung penelitian Wibowo et al. (2013) menunjukkan hasil penelitian bahwa kualitas pelayanan dan kepuasan memengaruhi niat beli ulang. Hasil ini menunjukkan kualitas layanan memiliki efek positif pada kepuasan kemudian pada niat beli ulang. Adixia (2013) menunjukkan bahwa kualitas pelayanan secara positif dan signifikan memengaruhi kepuasan pelanggan. Beberapa uraian di atas menunjukkan bahwa niat beli ulang dipengaruhi oleh kualitas layanan, tetapi beberapa di antaranya terlebih dulu didahului oleh kepuasan.

Responden dalam penelitian ini sebagian besar memiliki usia 18-21 tahun yaitu sebanyak 70 orang responden, mayoritas berjenis kelamin laki-laki. Jika dikaitkan dengan hasil penelitian, responden lakilaki lebih mengharapkan pelayanan yang lebih dan tidak didapat di pesaing dimulai dari pelayanan saat membuka situs hingga produk sampai di tangan mereka maka akan melakukan pembelian kembali di Lazada. Dengan mayoritas laki-laki yang dirasa lebih rasional dalam membanding-bandingkan ecommerce sebelum berbelanja membuat kualitas layanan menjadi menu utama dari pusat perbelanjaan non-fisik seperti Lazada. Peningkatan dan Maintenance dari layanan yang disajikan sudah seharusnya menjadi fokus utama Lazada ditengah gempuran penyedia layanan sejenis yang bisa mengambil pelanggan Lazada kapan saja.

\section{Pengaruh Kemudahan terhadap Niat Beli Ulang}

Hasil penelitian membuktikan pengaruh positif antara variabel kemudahan $\left(\mathrm{X}_{1}\right)$ terhadap variabel niat beli ulang (Y) studi pada pelanggan Lazada. Artinya, jika situs Lazada semakin mudah, niat beli ulang yang diberikan oleh konsumen juga akan menjadi lebih baik.

Hasil di atas mendukung penelitian oleh Wen et al. (2011) yang menyatakan bahwa faktor kemudahan akan secara langsung memengaruhi kepuasan dan niat beli ulang pada konsumen toko online. Chang (2012) juga menyatakan bahwa kemudahan penggunaan berefek positif pada manfaat yang dirasakan, kemudahan penggunaan yang baik dapat mengikatkan kepuasan yang baik, di mana hal tersebut terlihat dari pembelian berulang yang dilakukan. Beberapa uraian di atas menunjukkan bahwa niat beli ulang dipengaruhi oleh kemudahan dan didahului terlebih dahulu oleh kepuasan.

Berdasarkan karakteristik penelitian yang dilakukan ini menunjukkan bahwa sebagian besar responden yang mana adalah didominasi dengan jenis kelamin laki-laki berada pada usia 18-21 tahun di mana menunjukkan usia remaja akhir yang sudah dianggap mampu melakukan pembelian ulang. Kemudahan yang dirasakan oleh responden pada penelitian ini membuat mereka melakukan pembelian berulang. 
Dhimas Bagus Dwicahyanto. Peran E-Service Quality, Kemudahan, Kepuasan dalam Membentuk Niat Beli Ulang Konsumen Lazada

Maka dari itu Lazada akan dituntut tetap mudah diakses kapan saja dan mampu memberikan kepuasan yang sama seperti yang pelanggan terima pertama kali. Hal ini mengingat semakin banyaknya ancaman dari penyedia layanan sejenis karena kondisi pandemi covid-19 yang membuat pelanggan melakukan pola konsumsi yang berbeda.

\section{KESIMPULAN}

Hasil penelitian menunjukkan terdapat pengaruh positif dan signifikan antara variabel e-service quality (X1) terhadap kepuasan konsumen (Z) pada pelanggan Lazada, terdapat pengaruh positif dan signifikan antara variabel kemudahan (X2) terhadap kepuasan konsumen $(Z)$ pada pelanggan Lazada, terdapat pengaruh positif dan signifikan antara kepuasan konsumen $(\mathrm{Z})$ terhadap niat beli ulang (Y) pada pelanggan Lazada, tidak terdapat pengaruh positif dan signifikan antara e-service quality (X1) terhadap niat beli ulang $(\mathrm{Y})$ pada pelanggan Lazada, dan terdapat pengaruh positif dan signifikan antara kemudahan (X2) terhadap niat beli ulang (Y) pada pelanggan Lazada.

Batasan yang ada pada penelitian ini adalah responden dengan rentang usia 18-25 tahun yang telah disesuaikan berdasarkan survei yang dilakukan oleh APJII merupakan rentang usia sebagai pengguna internet terbanyak di tahun 2018, sehingga penelitian selanjutnya disarankan melakukan penelitian dengan cara memperluas jangkauan cakupan usia dan memperluas jangkauan pekerjaan selain mahasiswa sebagai responden. Karakteristik responden pada penelitian ini mayoritas berjenis kelamin laki-laki, sehingga penelitian selanjutnya disarankan untuk meneliti dengan responden yang seimbang jumlah prosentase jenis kelamin laki-laki dan perempuannya. Objek penelitian pada penelitian ini juga hanya difokuskan pada e-commerce dengan bentuk toko online $B 2 C$, oleh karena itu penelitian selanjutnya dapat meneliti bentuk e-commerce lain seperti marketplace, shopping mall, iklan baris, dan toko online pada $\mathrm{B} 2 \mathrm{~B}$ atau toko online $C 2 C$. Penelitian selanjutnya juga dapat melibatkan variabel kualitas produk, emotional factor, dan harga.

\section{REFERENCES}

A., Parasuraman, Valarie A. Zeithaml \& Malhotra Arvind. (2005). A Multiple-Item Scale for Assessing. Journal of Service Research, Volume 7, No. X.

Abid, M.M.F., \& P, Dinalestari. (2019). Pengaruh E-Security dan E-Service Quality Terhadap ERepurchase Intention Dengan E-Satisfaction Sebagai Variabel Intervening Pada Konsumen ECommerce Lazada di Fisip Undip. Diponegoro Journal Of Social And Politic, 1-8.

APJII. (2018). Hasil Survei Penetrasi dan Perilaku Pengguna Internet Indonesia 2018. (https://apjii.or.id/survei, diakses pada 20 Oktober 2019 jam 11:00)

Basu, Swastha DH. \& Irawan. (2008). Manajemen Pemasaran Modern. Edisi Kedua. Yogyakarta: Liberty Offset.

Basyar, K., \& Sanaji. (2016). Pengaruh Persepsi Kemudahan Dan Persepsi Manfaat Terhadapniat Beli Ulang Secara Online Dengan Kepuasan Sebagai Variabel Intervening. BISMA : Bisnis dan Manajemen, 8 (2), 204-217.

Berry, L.L, Parasuraman, A. and Zeithaml V. (1994). Improving Service Quality in America : Lessons Learned, Academy of Management Executive.

Bitner, Mary Jo, Zeithaml, Valarie A. (2003). Services Marketing. Edisi Ketiga. Boston MCGraw-Hill.

CNN Indonesia. (2019). Netizen Indonesia Paling Gemar Belanja Online. CNN. (https://www.cnnindonesia.com/teknologi/20190201173813-185-365769/netizen-indonesiapaling-gemar-belanja-online, diakses pada 20 Agustus 2019 jam 12:45) 
Chien-Chung Tu., Kwoting Fang., dan Chwen-Yea Lin. (2012). Perceived Ease of Use, Trust, and Satisfaction as Determinants of Loyalty in e-Auction Marketplace. Journal Of Computers. Vol. 7 (3): pp 645-652

Engel, J. F, et al. (1995). Perilaku Konsumen. Edisi Keenam. Jilid Kedua. Penerjemahan oleh F.X. Budiyanto. Jakarta: Binarupa Aksara.

Ghozali, Imam. (2013). Aplikasi Analisis Multivariate Dengan Program SPSS. Semarang : Badan Penerbitan Universitas Diponegoro.

ICSA. (2017). Winner ICSI 2017. (http://icsa-indo.com/winner/icsa_2017.html, diakses pada 14 Maret 2017 jam 10:30)

Juniwati. (2015). Pengaruh Perceived Ease of Use, Enjoyment dan Trust Terhadap Repurchase Intention dengan Customer Satisfaction Sebagai Intervening pada Belanja Online (Studi Pada Mahasiswa Universitas Tanjungpura Pontianak), Jurnal Ekonomi Bisnis dan Kewirausahaan, 4 (1), 140-156.

Kotler, Philip dan Gray Amstrong. (2004). Dasar-dasar pemasaran jilid 1. Edisi kesembilan. Terjemahan Drs. Alexandre Sindoro. Jakarta : PT. Indeks.

Kotler, Philip dan Kevin Lane Keller. (2009). Manajemen Pemasaran. Edisi Ketiga belas. Jakarta: Erlangga.

Lestari, S.W.A. (2019). Pengaruh Kemudahan Penggunaan Dan Keamanan Bertransaksi Online Melalui Aplikasi Shopee Terhadap Minat Pembelian Ulang Konsumen (Studi Pada Mahasiswa Administrasi Bisnis Angkatan 2015 - 2017 Universitas Mulawarman). eJournal Administrasi Bisnis, 7 (1), 262-275.

Lupiyoadi, Rambat dan A. Hamdani. (2008). Manajemen Pemasaran Jasa. Edisi Kedua. Jakarta: Salemba Empat

Malhotra, N.K. (2009). Riset Pemasaran, Edisi keempat, Jilid 1, PT Indeks, Jakarta.

Marzuki, Yunnie. (2017). Lazada Indonesia celebrates its 5th anniversary. (https://www.digitalnewsasia.com/business/lazada-indonesia-celebrates-its-5th-anniversary, diakses pada 14 Maret 2017 jam 11.00)

Nusaresearch. (2018). Situs Marketplace Mulai Mendominasi Pasar E-Commerce di Indonesia. (https://nusaresearch.net/public/index/index/redirect/_public_index_public-survey, diakses 17 Maret Jam 15:30)

Palma, M.A., \& Andjarwati, A.L. (2016). Pengaruh Kualitas Produk, Kemudahan, Dan Harga Terhadap Niat Beli Ulang Dengan Kepuasan Sebagai Variabel Intervening (Studi Pada Pelanggan Produk Fashion Melalui Toko online di Surabaya). Jurnal Riset Ekonomi dan Manajemen, 16, 84-104.

Pateli, A., Pappas, I., Glannakos, M., \& Chrissikopoulos, V. (2014). Moderating Effects of Online Shopping Experience on Customer Satisfaction and Repurchase Intentions. International Journal of Retail \& Distribution Management.

Purba, A.F.P., Nugraha, H.N., \& Nurseto, S. (2015). Pengaruh E - Service Quality Dan Product Quality Terhadap Intent to Online Repurchase Melalui E - Satisfaction Sebagai Variabel Intervening, Jurnal Ilmu Administrasi Bisnis.

Setyaningsih, Oktania. (2014). Pengaruh Persepsi Kualitas Layanan E-commerce Terhadap Kepuasan 
Dhimas Bagus Dwicahyanto. Peran E-Service Quality, Kemudahan, Kepuasan dalam Membentuk Niat Beli Ulang Konsumen Lazada

Pelanggan, Kepercayaan, dan Loyalitas Pada Produk Fashion, Jurnal Bisnis dan Manajemen, Vol 14 No 2.

Siregar, Boyke P. (2016) Pertumbuhan Aplikasi Lazada Capai 500 Persen. (https://www.wartaekonomi.co.id/read96804/pertumbuhan-aplikasi-lazada-capai-500-persen, diakses pada 15 Maret 2017 jam 09.30)

Sobel, M. E. (1982). Asymptotic Confidence Intervals for Indirect Effects in Structural Eequation Models. In S. Leinhardt (Ed.), Sociological Methodology. Washington DC: American Sociological Association.

Sumarwan, Ujang. (2014). Perilaku Konsumen Teori dan Penerapannya dalam Pemasaran. Bogor: Ghalia Indonesia.

Swastika, Vanessa M. (2015). Perkembangan Teknologi di Indonesia. (https://www.kompasiana.com/vanessams/55547634b67e615e14ba545b/perkembanganteknologi-di-indonesia, diakses pada 13 Maret 2017 jam 10.30)

Top Brand Award. (2018). Top Brand Index Situs Toko Online. (https://topbrand-award.com, diakses pada 17 Agustus 2018 jam 12:00)

Trusted Company. (2018). Trusted Company E-commerce. (https://trustedcompany.com, diakses pada 23 Juli 2018 jam 12:30)

Tuan, M. N. (2012). Effect of Service and Price Fairness on Student Satisfaction. International Journal of Business and Social Science Vol. 3 No. 19;132-150

Venturebeat. (2013). Samwer brothers-backed Lazada nabs \$100M to be the 'Amazon of Southeast. (https://venturebeat.com/2013/06/20/lazada-funding/, diakses pada 13 Maret 2017 jam 10.45)

Yusuf, Oik. (2014). Pengguna Internet Indonesia Nomor Enam Dunia. (https://tekno.kompas.com/read/2014/11/24/07430087/Pengguna.Internet.Indonesia.Nomor.Ena m.Dunia, diakses pada 1 Januari 2019). 